\title{
Autologous-Versus Allogeneic-Bone Marrow Cell Grafting in Prevention of Obstructive Nephropathy in Rats
}

\section{Original Article}

\author{
Islam omar Abdel Fattah', Manal H. AL Badawi, Mona Hassan Mohamed', \\ Alaaeldeen Saad Abdel Hameed ${ }^{3}$
}

${ }^{1}$ Department of Anatomy and Embryology, Faculty of Medicine, Suez Canal University

${ }^{2}$ Faculty of Medicine, Helwan University

${ }^{3}$ Department of Clinical Pathology, Faculty of Medicine, Suez Canal University

Background: The increasing number of patients suffering from chronic renal disease (CRD) and end-stage renal disease (ESRD) are a challenge for the development of ingenious therapies. Bone marrow (BM) stem cells are an attractive therapy in the treatment of CRD.

Aim of the work: This study aims to compare autologous and allogeneic BM cells in treatment of renal damage in a model of unilateral ureteral obstruction (UUO).

Materials and methods: Sixty adult female Sprague-Dawley rats were divided randomly into four groups of 15 animals each: Rats of first group served as (Sham group). The sham-operated animals underwent identical surgical procedures, except that the left ureter was manipulated without ligation and sectioning. Rats underwent UUO with direct intra-renal injection of saline were considered as (UUO) group. The remaining rats were injected with autologous (Auto group) or allogeneic (Allo group) BM cells directly into the renal parenchyma at the same day of operation. In Allo group, the ages of the donor rats were approximately the same as the recipient rats.

Results: In the present study, we showed that both types BM cells provided a protective effect and ameliorated interstitial fibrosis as reflected by reduced tubular dilation, decreased interstitial expression of .-smooth muscle actin and significant decline in expression of both transforming growth factor-. 1 and caspase-3 in the tubular cells. Autologous BM cells reduced the tubular dilation index from 36.6 (as in UUO rats) to 8.13. Allogeneic BM cells reduced tubular dilation index to 16.87. Conclusion: Our results show that a single intra-renal administration of autologous or allogeneic BM cells strongly associated with a reno-protective role with enhanced proliferation and reduced apoptosis of tubular cells promoted by UUO.

Received: 17 November 2018, Accepted: 30 December 2018

Key Words: Allogeneic, autologous, nephropathy, stem cells, unilateral ureteral obstruction.

Corresponding Author: Manal H. AL Badawi, MD, Faculty of Medicine, Helwan univercity, Cairo, Egypt, Tel.: +20 26410273, E-mail: manalalbadawi@yahoo.com

ISSN: $1110-0559$, Vol. 42, No. 2

\section{INTRODUCTION}

The epidemic of chronic renal disease (CRD) and endstage renal disease (ESRD) represents a crisis for healthcare burden world-wide ${ }^{[1]}$. Estimates of the global burden of disease indicate that diseases of the urinary system account for approximately 830,000 deaths and 18,467,000 disability-adjusted life years annually, estimating them $12^{\text {th }}$ among causes of death (1.4 percent of all deaths) and $17^{\text {th }}$ among causes of disability ${ }^{[2]}$.

Unilateral ureteral obstruction (UUO) animal models have been considered the classical models of obstructive renal injury because UUO can be easily manipulated by changing the time, severity and duration according to the experimental needs ${ }^{[3]}$. The advantage of the complete UUO model is good reproducibility, short time-course, easy surgical performance and the presence of the contralateral kidney for comparison ${ }^{[4]}$.

The kidneys are traditionally considered organs which are not able to self-regenerate ${ }^{[5]}$. Renal interstitial fibrosis is a progressive mechanism that ultimately leads to ESRD, which needs urgent dialysis or kidney transplantation ${ }^{[6]}$. Neither of these interventions can replace all functions of the kidneys, as there are other functions such as the secretion of erythropoietin which is essential for production of red blood cells ${ }^{[7]}$. Hence, alternative strategies have been pursued to develop new therapies for CRD.

In the last decade, the use of bone marrow (BM) cells has emerged as a new modality for treatment ${ }^{[8]}$. Recent studies 
have showed on techniques to mobilize the endogenous stem-cells to the injured kidneys or to introduce exogenous stem cells for tissue repair ${ }^{[9]}$.

Our investigation aimed to compare the autologous and allogeneic BM cells in modulating chronic renal injury produced with complete UUO. Our attention has been paid to key immune-histochemical markers of apoptosis and fibrosis, as well as tubular regeneration in this model of chronic tubule-interstitial damage and progressive loss of renal tissue.

\section{MATERIALS AND METHODS}

\section{Animals}

Sixty adult female Sprague-Dawley rats, aged 10 to 12 weeks old and weighed from 150 to 200 grams were included in our experiment. The rats were kept in a 12 -h light/dark cycle at $25^{\circ} \mathrm{C}$ and fed standard rat chow and water ad libitum and left at least 48 -h before the experiment to allow acclimatization.

\section{Ethical consideration}

ALL experiments were conducted in accordance with the guidelines of the Institutional Animals Ethics Committee of Suez Canal Uneversity.

\section{Experimental protocol}

The rats were anesthetized by intramuscular injection of $50 \mathrm{mg} / \mathrm{kg}$ of ketamine hydrochloride (Troikaa, Gujarat, India) and $5 \mathrm{mg} / \mathrm{kg}$ of xylazine (ADWA Co., 10th of Ramadan City, Egypt). After an abdominal midline incision, the left ureter was ligated using 6-0 silk at two points and severed between the two ligatures and the rats were kept in standard cages. They were divided randomly into 4 groups of 15 animals.

1. Sham group: First group served as sham-operated controls. The sham-operated animals underwent identical surgical procedures, except that the left ureter was manipulated without ligation and sectioning.

2. UUO group: rats underwent UUO with direct intra-renal injection of saline.

3. Auto group: rats underwent UUO and injected with autologous BM cells directly into the renal parenchyma at the same day of operation.

4. Allo group: rats underwent UUO and injected with allogenic BM cells directly into the renal parenchyma at the same day of operation.

In Allo group, the ages of the donor rats were approximately the same as the recipient rats. All groups received antibiotics in their drinking water $(0.1 \%$ amoxicillin [EIPICO, $10^{\text {th }}$ of Ramadan City, Egypt] and $0.015 \%$ enrofloxacine [Nile Co., Cairo, Egypt]) till the day of scarification to prevent pyelonephritis as done before by Barreira et al. ${ }^{[10]}$ and also given $5 \mathrm{mg} / \mathrm{kg} / \mathrm{d}$. of carprofen (Norbrook, Newry, Northern Ireland) by intra-peritoneal injection for the first two days as done by Zhang et al. ${ }^{[11]}$.

These animals were sacrificed on day 10 of UUO because remodeling of tubular cells is already high at this point as we concluded in a preliminary pilot study.

Control groups, i.e. rats not submitted to any surgical procedure were not included in this study, since previously we had found no histological difference between control and sham groups in a preliminary pilot study.

\section{Harvesting the autologous or allogeneic BM}

After anesthesia in rats of Auto group, as described above in the UUO operation, or scarification of the donor rats for Allo group, the skin and femoral fascia of lateral area of the left thigh were incised. The muscles were splitted and the femur was exposed was drilled using a dental scaler. An intravenous cannula was inserted into the medullary cavity through the hole. The BM was flushed out with phosphate buffered saline (PBS) introduced through the cannula then aspired again.

\section{Preparation of mononuclear cell (MNC) suspension from BM Plug.}

Isolation of MNCs were done according to Fontes et al. ${ }^{[12]}$ After removing all $\mathrm{BM}$ in $3 \mathrm{ml}$ PBS containing $10 \% \mathrm{FBS}$, it was centrifuged for 5 minutes at $160 \mathrm{~g}$. The supernatant was removed and the precipitated fraction was resuspended in $1 \mathrm{ml}$ of PBS with $10 \%$ fetal bovine serum (FBS). The suspension was added over $0.5 \mathrm{ml}$ of Ficoll-Paque. Centrifugation was performed at $400 \mathrm{~g}$ for $15 \mathrm{~min}$. The result of this step was a three layered solution where the middle layer that contained the BM-MNCs. A pipette was used to extract the middle layer.

\section{Intrarenal injection of BM-MNCs}

The injection has been performed in three different areas in the medial longitudinal axis of the kidney as described previously ${ }^{[13]}$.

\section{Tissue preparation}

The left kidneys were removed and cleared from the extraneous tissues and weighed. The kidneys were fixed by submersion in $10 \%$ neutral buffered formaldehyde solution for at least 24-h then were sectioned midfrontally into 2 pieces and then embedded into paraffin wax.

\section{Histopathological assessment}

For histological evaluation, sections $4 \mu \mathrm{m}$ thick were cut from the paraffin blocks and stained with hematoxylineosin (H\&E), Masson's trichrome for collagen plus periodic acid-Schiff (PAS) reagent stains to visualize basement membrane. Pictures were captured by an Olympus optical microscopy (magnification: 40X).

Hematoxylin\& Eosin (H\&E) stain is used to assess the glomeruli as regard the thickness of the capsular basement membrane, dilatation of the Bowman's space, glomerular basement membrane, mesangial cells and mesangial matrix. Also it assesses the tubule as regard the basement 
membrane. Tubular dilatation and tubular atrophy. It assesses the interstitium as regard the expansion by either edema, inflammatory cells, or fibrous tissue.

Periodic Acid Schiff (PAS) stains the capsular, glomerular and tubular basement membrane. Also it stain the mesangial fibrotic deposit.

Masson's trichrome stains the collagen of the fibrous tissue in either interstitium or mesangial area.

\section{Immunohistochemical assessment}

Immunodetection of caspase-3, transforming growth factor- $\beta$ (TGF- $\beta 1)$ and $\ddot{\alpha}$-smooth muscle actin ( $\ddot{\alpha}$-SMA) was performed in kidney paraffin-embedded sections. After deparaffinized and hydration, tissue was stained with anti- Caspase-3 antibody (Sigma BioSciences), with purified mouse TGF- $\beta$ antibody (Novus Biologicals) or with murine monoclonal anti- $\bar{\alpha}-\mathrm{SMA}$ (Sigma BioSciences) according to manufacturer's instruction. Interpretation of results was done semiquantitatively by evaluating both intensity and distribution of positive tissues.

Monoclonal antiCaspase-3 highlights the apoptotic tubular cells. Monoclonal anti transforming growth factor- $\beta$ (TGF- $\beta 1$ ) determines the fibrous tissue either in the interstitium or mesangium. Monoclonal anti- $\bar{\alpha}-\mathrm{SMA}$ is uses to assess the interstitial fibrosis.

\section{Gross morphometry}

Hydronephrosis were assessed semiquantitatively as described previously ${ }^{[14]}$. The following criteria were used: $0=$ normal (finger-in-glove configuration of the papilla and calyx); $1=$ minimal ( a narrow but definable fluid-filled calyceal space with normal papillary contour): $2=$ moderate (unequivocal dilatation of the calyx. with compression of the papilla, but with preservation of its conical shape); $3=$ marked (gross distension of the calyx, typically increasing overall volume of the kidney by at least $50 \%$, and resulting in severe compression of the lateral cortex and distortion of the papilla).

\section{Histomorphometry}

At all histomorphological evaluations, five different randomly selected sections were examined form each left kidney and from each section five different nonoverlapping slides were analyzed by a blinded observer.

Incidence of hydronephrosis, tubular dilation, and focal and segmental glomerular sclerosis were assessed as described before ${ }^{[14]}$. A score ranging from 0 (no lesions) to 3 (extensive lesions). Specifically, the grading scale used was: $0=$ absent/normal; $1=$ minimal, few instances seen throughout the sections; $2=$ moderate, instances easily found, most areas normal; 3 = extensive, instances found in nearly all 40X fields.

Tubular dilatation index and interstitial volume index were assessed morphometrically as described before ${ }^{[15]}$. In brief, a grid containing $117(13 \times 9)$ sampling points was superimposed on images $(40 \mathrm{X})$ from sections stained with PAS reagent (Fig. 1). The number of grid points overlying the tubular lumen (tubular dilation index) and interstitial space (interstitial volume index) was counted and expressed as a percentage of all sampling points.

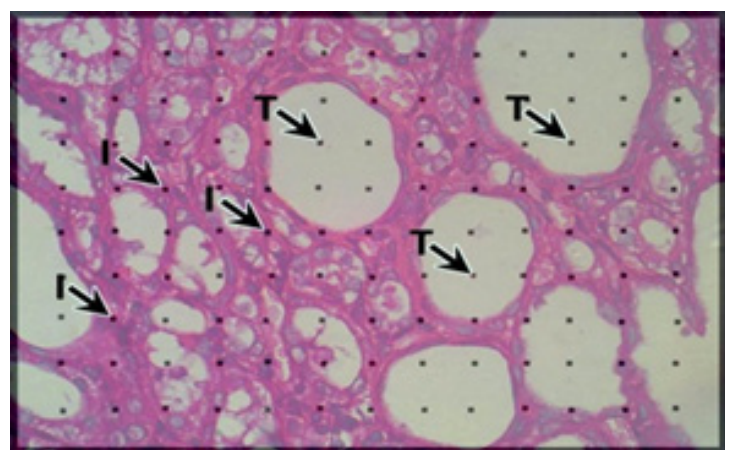

Fig. 1: Grid method for evaluation of the tubular dilatation index and the interstitial volume index. (I) points lie on the interstitium and (T) points are on the tubular lumens.

\section{Statistical Analysis}

Mean $\pm \mathrm{SE}$, Chi-square test and one-way ANOVA test were performed using SPSS window 16.0 version. Statistical significance was set at $P<0.05$.

\section{RESULTS}

\section{Weights and external appearance of the kidneys}

After left-sided UUO rats developed hydronephrosis with progressive dilation of the renal pelvises and ureters. The kidneys were spherical and pale in color. In the Auto and Allo groups the kidneys became darker, bean-shaped, and with less distended pelvises and ureters (Fig. 2).

In UUO group, the left kidneys' weights ( mean $=2.55$ gm) were significantly increased compared to weights in Sham group $($ mean $=0.508 \mathrm{gm})$. Weights of left kidneys in Auto $($ mean $=1.944 \mathrm{gm})$ and Allo $($ mean $=1.91 \mathrm{gm})$ groups were significantly reduced compared to UUO group, although the difference between Auto and Allo groups was statistically non-significant (Histogram 1).

\section{Gross morphometry}

In grading of the kidneys according to hydronephrosis, most of rats of UUO group (11 rats) had grade (3) hydronephrosis (Histogram 2), with almost flat renal papillae (Fig. 3). In contrast, most of rats of Auto group (7 rats) and Allo group (9 rats) had grade (2) hydronephrosis with almost preservation of the conical appearance of the renal papillae (Fig. 3).

\section{Histopathological assessment}

The kidneys exhibited some glomerular shrinkage, expansion of the interstitium, and tubular damage 10 days after obstruction (Fig. 4). Tubular damage was characterized by dilation with flattened epithelium, atrophy, and necrosis there were fibrotic deposits seen by Masson's stain (Fig. $5)$ and type IV collagen deposits, especially around Bowman's capsules, seen by PAS stain (Fig. 6). This was 
partially prevented in BM cells-treated groups, where the glomeruli and the tubules regained most of their contour and the interstitium was reduced with reduced interstitial and pericapsular collagen deposits.

Although both autologous and allogeneic BM cells reduced the glomerular and the tubulointerstitial damage, but there was no distinct difference between both groups in prevention of the damage detected by the histological investigations.

\section{Immunohistochemical assessment}

Caspase-3 expression in UUO group was in form of deeply stained cytoplasm and nuclei of most of the tubular cells that was reduced in Auto and Allo groups. In Auto group, there were few positively stained nuclei and in Allo group there were few tubular cells with stained cytoplasm (Fig. 7).

In UUO rats, the left kidneys showed high immunoexpression of TGF- $\beta$ in form of punctate brown extensive granules that encroach on the nuclear boundaries in most of tubular cells. This expression was highly reduced in both Auto and Allo groups that showed lightly stained cytoplasm in some tubular cells (Fig. 8).

Myofibroblasts were very detectable by $\ddot{\alpha}$-SMA immunostaining in UUO group that was mostly minimized in both Auto and Allo groups in form of faint deposits around the tubules and glomeruli (Fig. 9).

Generally, the difference in histopathological and immunohistochemical between Auto and Allo groups was not greatly noticeable.

\section{Histomorphometry}

With evaluation of the grades of incidence of hydronephrosis, tubular dilation, and focal and segmental glomerular sclerosis, most of rats (10 rats) were categorized as grade (3) in UUO group, while most rats (8 rats) in Auto group had grade (2) and most rats (6 rats) in Allo group had grade (1) (Histogram 3).

Estimation of the tubular dilatation index showed that an increase in UUO group (mean $=36.6)$ that was significant when compared with that of Sham group (mean $=2.29)$. The index was reduced in Auto $($ mean $=8.13)$ and Allo (mean $=16.87$ ) groups. The difference between UUO group and both BM-treated groups is statistically significant (Table 1).
According to interstitial volume index, it was highly increased in UUO group ( mean $=55.73$ ) with a significant increase when compared with Sham group (mean $=5.47$ ). The index was reduced in Auto $($ mean $=29.53)$ and Allo $($ mean $=29.47)$ groups .

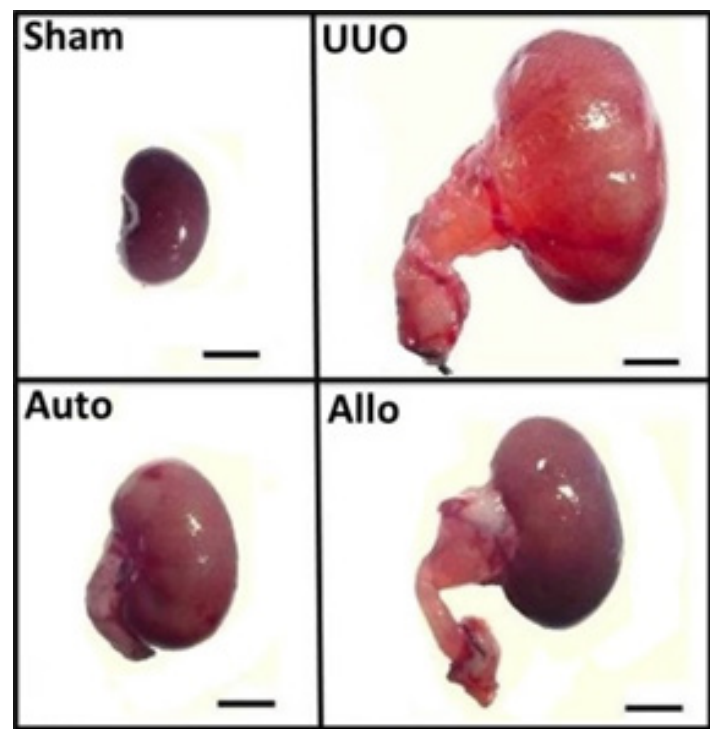

Fig. 2: Gross picture of a left kidney from each group. The UUO rat's left kidney is pale, spherical and with highly dilated pelvis compared to the other groups. Scale bars $=5 \mathrm{~mm}$.

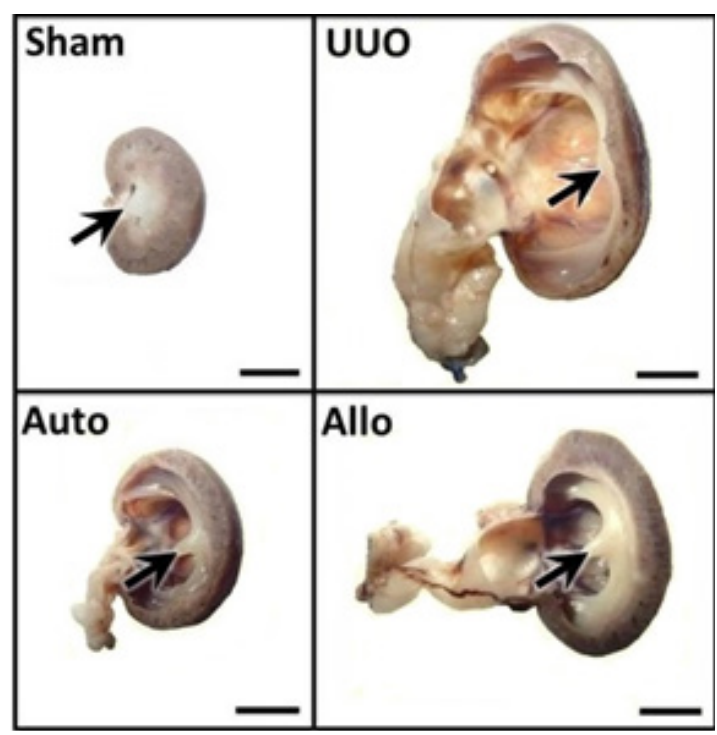

Fig.3: Cross section of a left kidney from each study group. The arrows refer to renal papillae which is compressed in UUO group and conical in Sham, Auto and Allo groups. Scale bars $=5 \mathrm{~mm}$. 


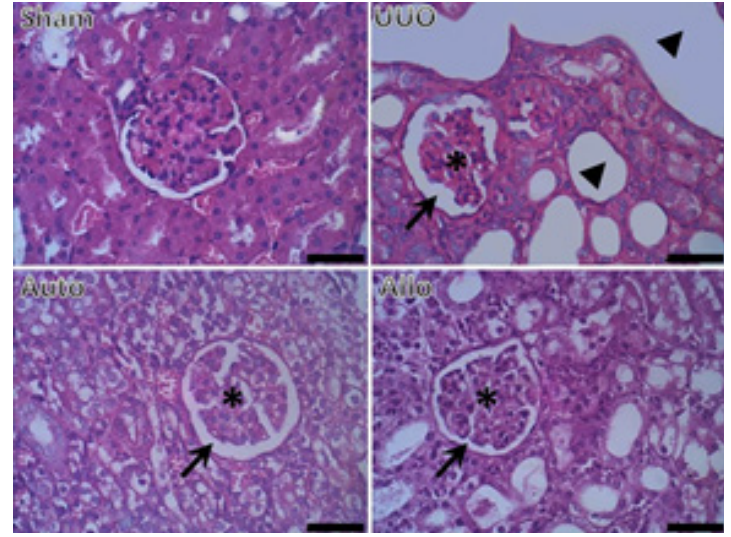

Fig.4: Photomicrograph of a sections of kidney of Sham, UUO, Auto and Allo rats. Kidney section of UUO group shows dilated Bowman's space (arrows) and renal tubules (arrow heads). The shown glomerulus is shrunken (asterisk) and the interstitium is expanded by fibrosis. In both Auto and Allo groups, the glomeruli are mostly not shrunken (asterisk), the Bowman's spaces are not dilated (arrows), and with little dilated tubules and minimally expanded interstitium. Scale bars $=40 \mu \mathrm{m}$. (H\&E x400)

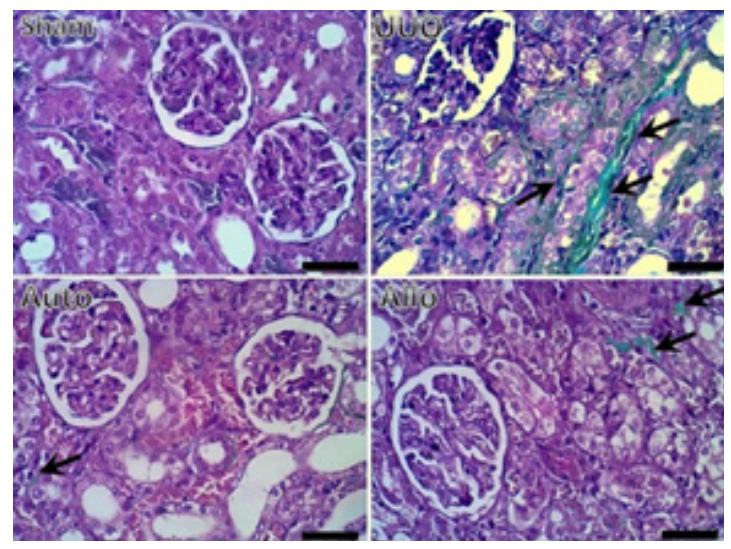

Fig. 5: Photomicrograph of kidney sections from the four study groups, showing fibrotic deposits (arrows) that are extensive in UUO group and highly reduced in both BM treated groups. Scale bars $=40 \mu \mathrm{m}$. (Masson's tricrome $\mathrm{x} 400$ )

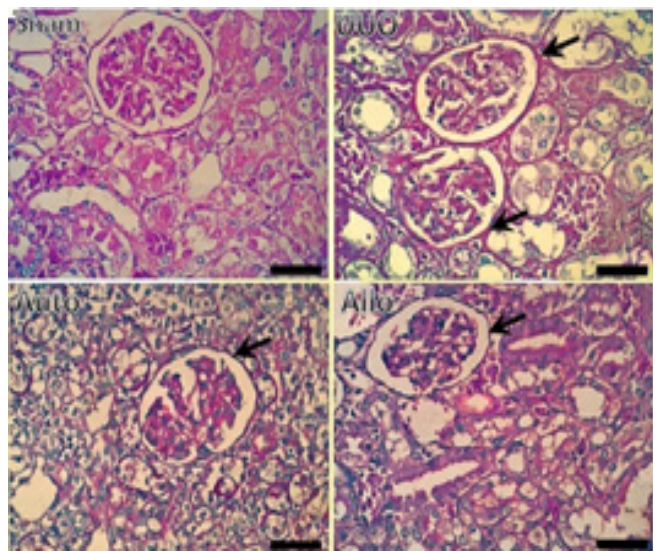

Fig. 6: Photomicrography of PAS-stained kidney sections from the four study groups, showing thickened capsular basement membrane (arrows). In UUO section, the thichening is extensive, while the thickening is greatly reduced in both Auto and Allo groups. Scale bars $=40 \mu \mathrm{m}$. (PAS $\mathrm{x} 400$ )

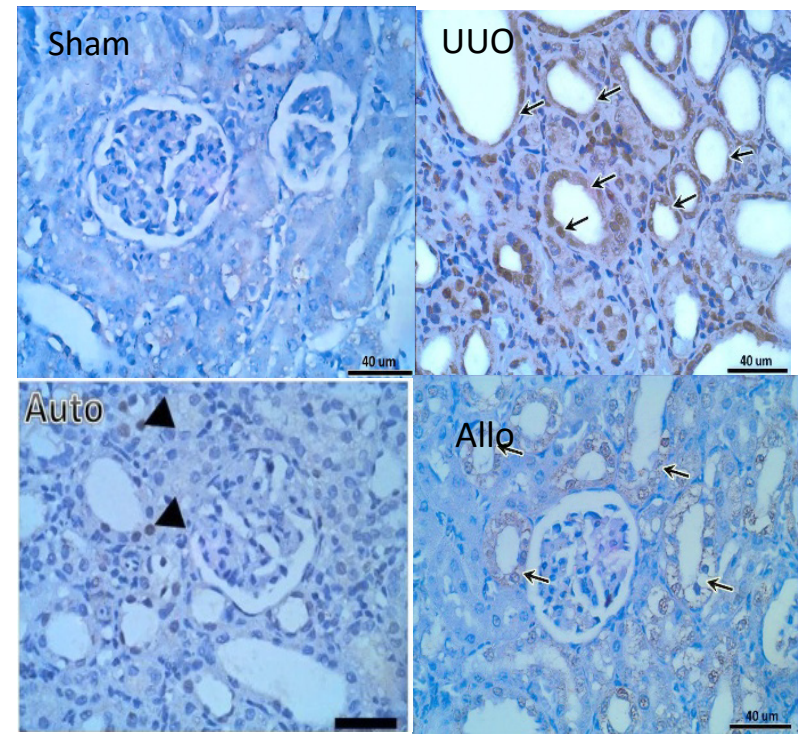

Fig.7: A Photomicrograph of expression of caspase-3 in renal tissues of the four study groups. The immunoexpression is high in UUO group in form of deeply cytplasmic staining (arrow). In Auto and allo group, there are few immunoreactive cell (arrow head and arrow respectively). Scale bars $=40 \mu \mathrm{m}$. (Caspase-3 immuno-stain $\mathrm{x} 400)$

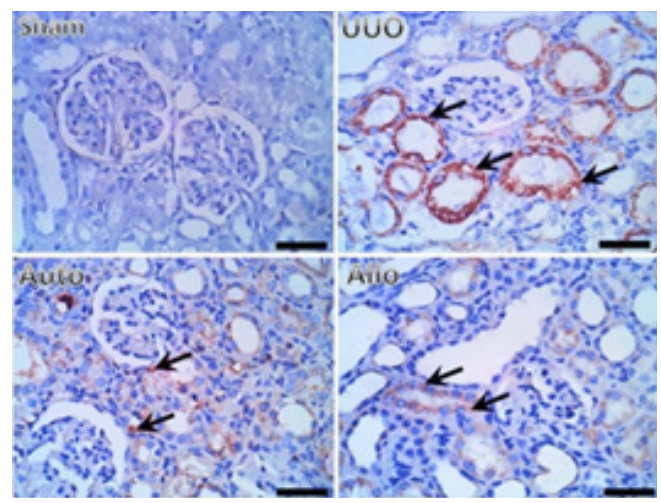

Fig. 8: A Photomicrograph of expression of TGF- $\beta$ in renal tissues of the four study groups. The stain is deeply concentrated in form of massive cytoplasmic expression in UUO group (arrows), while is highly reduced in both Auto and Allo groups in form of faint cytoplasmic expression (arrows). Scale bars $=40 \mu \mathrm{m}(\mathrm{TGF}-\beta$ immuno-stain $\mathrm{x} 400)$

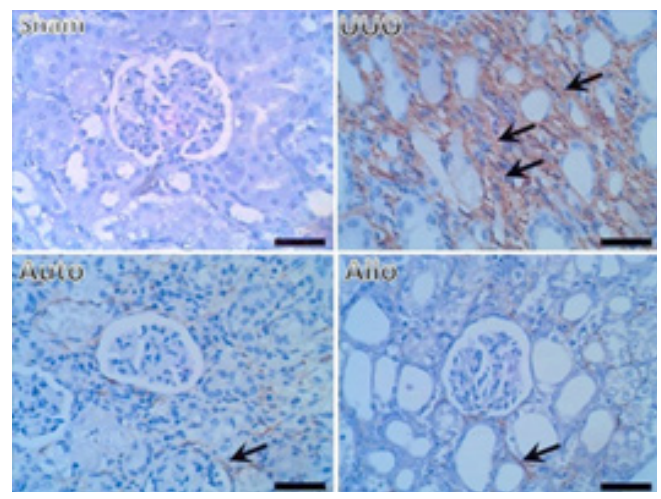

Fig. 9: A Photomicrography of $\ddot{\alpha}-$ SMA stained renal sections. The arrows indicate cytoplasmic expression of the stained tubular cells, which are very extensive in UUO group and minimally detected in Auto and Allo groups. Scale bars $=40 \mu \mathrm{m}$. (㑒-SMA immuno-stain $\mathrm{x} 400)$ 
Table 1: Mean $\pm \mathrm{SE}$ of renal pelvic diameter and parenchymal thickness o left kidneys of different groups.

\begin{tabular}{lcc}
\hline Group & Tubular dilatation index & Interstitial volume index \\
\hline Sham & $2.29 \pm 1.33$ & $5.47 \pm 0.49$ \\
UUO & $36.60 \pm 3.12^{\mathrm{a}}$ & $55.73 \pm 2.78^{\mathrm{d}}$ \\
Auto & $8.13 \pm 0.87^{\mathrm{b}}$ & $29.53 \pm 1.98$ \\
Allo & $16.87 \pm 1.41^{\mathrm{c}}$ & $29.47 \pm 2.49$ \\
\hline
\end{tabular}

a. The independent T-test Pvalue $<0.0001$ vs. neg. and pos. cont. subgroups (very high significant).

b. The independent T-test Pvalue $<0.05$ vs. UUO group (significant).

c. The independent T-test Pvalue $<0.05$ vs. UUO group (significant).

$\mathrm{d}$. The independent T-test Pvalue $<0.05$ vs. neg. and pos. cont. subgroups ( significant).

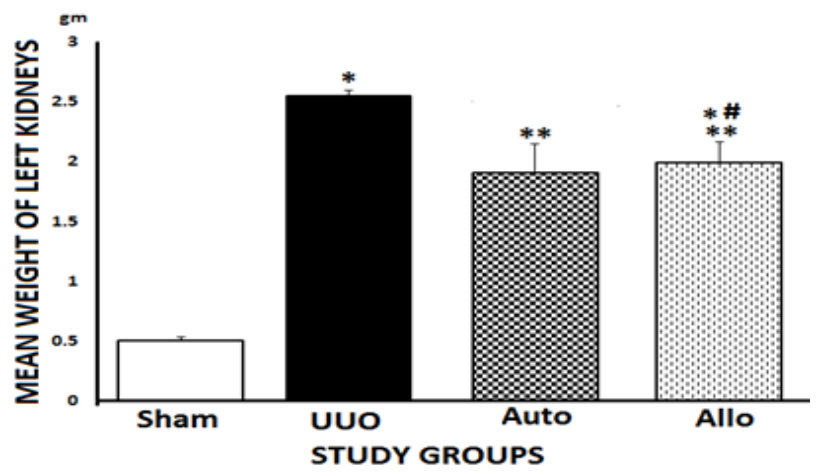

Histogram 1: Graphic representation (means $\pm \mathrm{SE}$ ) of kidney weight of each study group.

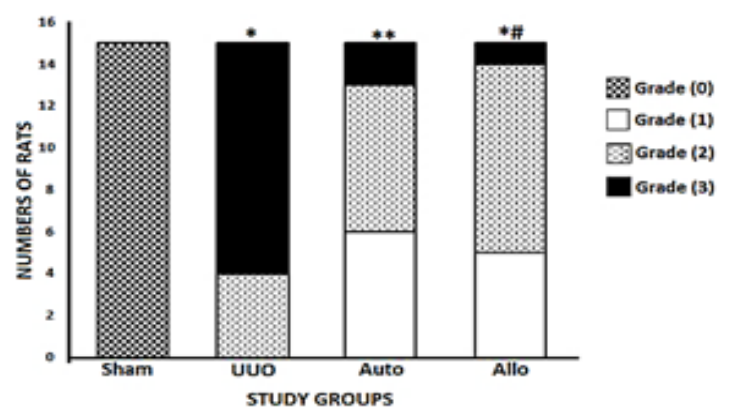

Histogram 2: Graphic representation of grading of hydronephrosis in left kidneys according to their gross evaluation of each study group. Chi square $* P<0.0001$ vs Sham group, $* * P<0.01$ vs UUO group and *\# $P>0.001$ vs UUO group.

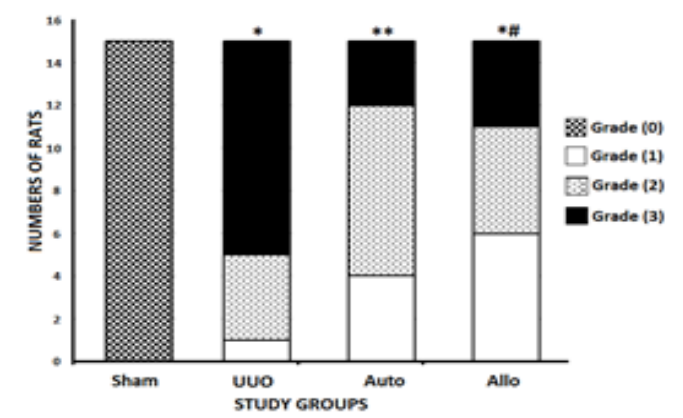

Histogram 3: Graphic representation of grading according to incidence of hydronephrosis, tubular dilation, and focal and segmental glomerular sclerosis. Chi square $* P<0.0001$ vs Sham group, $* * P<0.05$ vs UUO group and $* \# P<0.05$ vs UUO group.

\section{DISCUSSION}

CRD is a prevalent disease $(8-16 \%)$ associated with all-cause and cardiovascular mortality. Importantly, CRD can progress towards ESRD. At this situation, becomes renal replacement therapy is mandatory ${ }^{[16]}$. Current renal replacement therapeutic options is still limited to either peritoneal-dialysis, hemodialysis or kidney transplantation $^{[17]}$. Shortage of compatible organs together with limited adaptability of current dialysis techniques led to urgent need to search about other alternative choices ${ }^{[18]}$. Investigations have directed toward development of an effective cell therapy, which promised some hope for certain well known nephropathies ${ }^{[19]}$.

Interest in obstructive renal disease has been rekindled by our need to study the mechanisms of tubulointerstitial injuries. UUO is one of the most used models of fibrosing renal diseases. The UUO model has the advantages of reproducibility with little inter-animal variation, a short time-course and the surgery is relatively easy to perform, even in the mouse ${ }^{[20]}$.

The present study revealed tubular atrophy evidenced by tubular dilatation with flat epithelial lining, and significant reduction in parenchymal thickness. Interstitial expansion by edema, inflammatory cells and fibrous tissue is also evident in the model of UUO. These results were in agreement with Sorensen and Stoller $(2011)^{[21]}$. However, Sorensen and Stoller (2011) referred tubular atrophy in obstructive nephropathy to progressive ischemia of the tubular cells ${ }^{[21]}$. Padanikm (2003) reported that an increase in intratubular pressure leads to renal vasoconstriction and ischemia. These ischemic tubular cells underwent apoptosis and necrosis ${ }^{[22]}$. The interstitial fibrosis associated with UUO was confirmed by an increase in the cytoplasmic expression of TGF- $\beta 1$ in the affected tubular cells, and

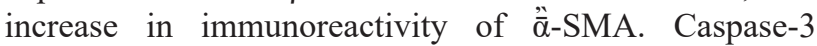
immunoreactivity in the tubular epithelium, was increased which indicates high apoptotic indices.

In addition, signs of healing could be detected in the present study in the form of multiple large pale vesicular nuclei in the renal interstitium. Some of these nuclei were seen occupying the tubular lumen. Also these nuclei could be detected in the parietal layer of Bowman's capsule.

Oliver et al. (2004) found proliferating renal specific progenitor cells in the renal tubules and papillae. They added that, after renal injury these cells could invade the kidney and differentiate into tubular and mesangial cells ${ }^{[23]}$. Also Park et al. (2010) described renal stem cell niche but they concluded that the renal capsule is a potential stem cell niche ${ }^{[24]}$. Moreover Fanni et al. (2015) detected stem cell niche in Bowman's capsule, where progenitor cells exist intermingled with parietal epithelial cells ${ }^{[25]}$.

Al-Awqati and Oliver (2006) recorded presence of stem cell niche in renal interstitium outside the proximal convoluted tubules. They recorded that these stem cells 
received damage signals from the cortex resulting in their proliferation and migration to the site of injury ${ }^{[26]}$.

Nandhini (2014) and Park et al. (2013) reported that TGF- $\beta 1$ and its receptors are highly up-regulated in the fibrotic kidney and TGF- $\beta 1$ acts as chemotactic factor for fibroblasts. It stimulates collagen production in kidney following chronic inflammation ${ }^{[27,28]}$.

TGF- $\beta$ was a key player in renal epithelial to mesenchymal transition (EMT). EMT is a process in which renal tubular cell lost their epithelial phenotypes and acquired new characteristic features of mesenchymal cells $^{[29,30]}$. According the role of EMT in the renal injury, recent therapeutic interventions in renal fibrosis are aimed to inhibit the fibroblast formation by shifting local cytokine balance in favor of reversal mesenchymal to epithelial transition $^{[31]}$.

As regards stem cell therapy, local injection of autologous BM cells resulted in an improvement of kidney structure. There was amelioration of tubular lesion, reduction of apoptosis and rapid tubular regeneration in rats. This was accompanied with decrease in caspase-3,

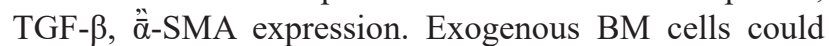
engraft into injured tubules and trans-differentiated into functional tubular cells ${ }^{[32]}$.

In the present study, local injection of allogeneic BM cells resulted in partial improvement of histological and immuno-reactivity of the kidney. However, some tubules were showing some sort of dilatation. The interstitium was highly cellular.

Our result was concordant with Gratwohl (2011) which declared that allogeneic stem cells were linked with immunological complications, graft rejection or rejection of recipient with the immune-competent transplanted immune system. The time of recovery to complete immunocompetence is considerable larger in allogeneic stem cells than in autologous stem cells ${ }^{[33]}$.

Also Togl et al. (2009) compared the outcomes of renoprotection after injection of autologous or allogeneic BM stem cells in rat acute kidney injury model. They found that identical doses of autologous mesenchymal stem cells were more effective than allogeneic cells but both were able to decrease the renal fibrosis and function in survived rats ${ }^{[34]}$.

\section{CONCLUSION}

In conclusion, our results show that a single intrarenal administration of autologous or allogeneic BM cells strongly reduce both collagen deposition and the myofibroblast population, associated with a reno-protective role with enhanced proliferation and reduced apoptosis of tubular cells promoted by UUO. There is no significant statistical difference between both sources of BM cells in this protective role, however the histological improvement is better in the autologous cell treatment.

\section{CONFLICTS OF INTEREST}

There is no conflict of interest to declare.

\section{REFERENCES}

1. Song B, Smink AM, Jones CV, Callaghan JM, Firth SD, Bernard CA, Laslett AL, Kerr PG and Ricardo SD. The directed differentiation of human iPS cells into kidney podocytes, Plos one (2012); 7(9): e46453

2. Dirks J, Remuzzi G, Horton S, Schieppati A and Rizvi SA. Diseases of the kidney and the urinary system, in: Jamison DT, Breman JG, Measham AR, Alleyne G, Claeson M, Evans DB, Jha P, Mills A and Musgrove P (Eds.), Disease Control Priorities in Developing Countries, 2nd edition, World Bank, Washington (2006) pp: 695-706

3. Yuan Y, Zhang F, Wu J, Chen Shao and Gao Y. Urinary candidate biomarker discovery in a rat unilateral ureteral obstruction model, The FASEB Journal (2015); 29(1): 567-562

4. Manucha W., Biochemical-molecular markers in unilateral ureteral Obstruction, Biocell (2007); 31(1): $1-12$

5. Flaquer M, Romagnani P and Cruzado JM. Growth factors and renal regeneration, Nefrologia (2010); 30(4): 385-393

6. Zhang D, Sun L, Xian W, Liu F, Ling G, Xiao L, Liu Y, Peng Y, Haruna Y and Kanwar YS. Lowdose paclitaxel ameliorates renal fibrosis in rat UUO model by inhibition of TGF-b/Smad activity, Laboratory Investigation (2009), 90: 436-447

7. Lee YC. Kidney failure and dialysis: a problemsolving approach in teaching science, technology and society, School Science Review (2006); 87(320): pp. 119-123

8. Barreira AL, Takiya CM, Castiglione RC, MaronGutierrez T, Barbosa CM, Ornellas DS, Verdoorn KS, Pascarelli BM, Borojevic R, Einicker-Lamas M, Leite M Jr, Morales MM and Vieyra A. Bone marrow mononuclear cells attenuate interstitial fibrosis and stimulate the repair of tubular epithelial cells after unilateral ureteral obstruction. Cell Physiol Biochem. (2009); 24(5-6): 585-594

9. Yokote S, Yamanaka S and Yokoo T. De novo kidney regeneration with stem cells. J Biomed Biotechnol. (2012): 453519

10. Barreira AL, Takiya CM, Castiglione RC, MaronGutierrez T, Barbosa CM, Ornellas DS, et al. Bone marrow mononuclear cells attenuate interstitial fibrosis and stimulate the repair of tubular epithelial cells after unilateral ureteral obstruction. Cell Physiol Biochem (2009); 24(5-6): pp. 585-594 
11. Zhang Q, Cuartas E, Mehta N, Gilligan J, Ke HZ, Saltzman WM, Kotas M, Ma M, Rajan S, Chalouni $\mathrm{C}$, Carlson J and Vignery A. Replacement of bone marrow by bone in rat femurs: the bone bioreactor, Tissue Eng (2008); 14(2): 237-246

12. Fontes EB, Borges AP, Pippi NL, Rosa M, Sprada A and Togni M. Overlapping of mononuclear cells derived from bone marrow in rats' intervertebral discs: an in vitro study, Ciência Rural, Santa Maria (2010); 40(4): 900-906

13. Alfarano C, Roubeix C, Chaaya R, Ceccaldi C, Calise D, Mias C, Cussac D, Bascands JL and Parini A. Intraparenchymal injection of bone marrow mesenchymal stem cells reduces kidney fibrosis after ischemia-reperfusion in cyclosporineimmunosuppressed rats, Cell Transplant. (2012); 21(9): 2009-2019

14. Vora JP, Zimsen SM, Houghton DC and Anderson $S$. Evolution of metabolic and renal changes in the ZDF/Drt-fa rat model of type II diabetes, J Am Soc Nephrol (1996); 7: 113-117

15. Vielhauer V, Anders HJ, Mack M, Cihak J, Strutz F, Stangassinger M, Luckow B, Gröne HJ, Schlöndorff D. Obstructive nephropathy in the mouse: progressive fibrosis correlates with tubulointerstitial chemokine expression and accumulation of CC chemokine receptor 2- and 5-positive leukocytes, J Am Soc Nephrol. (2001); 12(6): 1173-1187

16. Eirin A and Lerman LO. Mesenchymal stem cell treatment for chronic renal failure, Stem Cell Res Ther. (2014); 5(4): 83

17. Uzarski JS1, Xia Y, Belmonte JC and Wertheim JA. New strategies in kidney regeneration and tissue engineering, Curr Opin Nephrol Hypertens. (2014); 23(4): 399-405

18. Gabr H and Zayed RA. Mesenchymal stem cell infusion in chronic renal failure patients, jomb (2015), 4(4): 329-331

19. Watorek E and Klinger M. Stem cells in nephrology: present status and future, Arch Immunol Ther Exp, (2006); 54: 45-50

20. Becker GJ and Hewitson TD. Animal models of chronic kidney disease: useful but not perfect, Nephrol Dial Transplant. (2013); 28(10): 24322438

21. Sorensen MD, and Stoller ML. Obstructive uropathy, in: Lerma EV, and Nissenson AR (Eds.), Nephrology secrets, 3rd edition, Elsevier Mosby, Philadelphia. (2011); pp: 119-122

22. Padanikm BJ. Cell death induced by acute renal injury a perspective on the contributions of apoptosis and necrosis, American journal of physoiology (2003); v 284 issue 4 p f608-f627
23. Oliver JA, Maarouf O, Cheema FH, Martens TP and Al-Awqati Q. The renal papilla is a niche for adult kidney stem cells, J Clin Invest. (2004); 114(6): 795-804

24. Park HC, Yasuda K, Kuo MC, Ni J, Ratliff B, Chander P and Goligorsky MS. Renal capsule as a stem cell niche, Am J Physiol Renal Physiol. (2010); 298(5): 1254-1262

25. Fanni D, Sanna A, Gerosa C, Puddu M, Faa G and Fanos V. Each niche has an actor: multiple stem cell niches in the preterm kidney, Ital J Pediatr. (2015); 41(1): 78

26. Al-Awqati Q and Oliver JA. The kidney papilla is a stem cells niche. Stem Cell Rev. (2006); 2(3):1814.

27. Nandhini T. Molecular mechanism in renal fibrosis:a review, J. Pharm. Sci. and Res. (2014); 6(10): 334-337

28. Park J, Lee SY, Ooshima A, Yang KM, Kang JM, Kim YW and Kim SJ. Glucosamine hydrochloride exerts a protective effect against unilateral ureteral obstruction-induced renal fibrosis by attenuating TGF- $\beta$ signaling, J Mol Med (Berl) (2013); 91(11): 1273-1284

29. Ding Y and Choi ME. Regulation of autophagy by TGF- $\beta$ : emerging role in kidney fibrosis, Semin Nephrol (2014); 34(1): 62-71

30. Liu Y. Epithelial to mesenchymal transition in renal fibrogenesis: pathologic significance, molecular mechanism, and therapeutic intervention, J Am Soc Nephrol (2004); 15(1): pp. 1-12

31. Ross MH and Pawlina W. Histology: A Text and Atlas: with correlated cell and molecular biology, 6th edition, Lippincott Williams and Wilkins, Baltimore. (2011); p: 720

32. Qi $\mathrm{S}$ and $\mathrm{Wu}$ D. Bone marrow-derived mesenchymal stem cells protect against cisplatininduced acute kidney injury in rats by inhibiting cell apoptosis, Int J Mol Med (2013); 32(6): 12621272

33. Gratwohl A, Brand R, Niederwieser D, Baldomero $\mathrm{H}$, Chabannon $\mathrm{C}$, Cornelissen $\mathrm{J}$, de Witte $\mathrm{T}$, Ljungman P, McDonald F, McGrath E, Passweg J, Peters C, Rocha V, Slaper-Cortenbach I, Sureda A, Tichelli A. and Apperley J. Introduction of a quality management system and outcome after hematopoietic stem-cell transplantation. J Clin Oncol. (2011); 29:1980-6.

34. Tögel F, Cohen A, Zhang P, Yang Y, Hu Z and Westenfelder C. Autologous and allogeneic marrow stromal cells are safe and effective for the treatment of acute kidney injury, Stem Cells Dev. 2009; 18(3): 475-485 


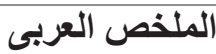

\section{خلايا النخاع العظمى الأتية مقابل خلايا النخاع العظى الغير الذاتية فى تحسين الإعتلال الكلوى الإنسدادى فى إناث الفئران البالغة البهانة}

أسلام عمر عبد الفتاح'، منال حمدى البدوى ‘، منى حسن محمد' ،علاء الدين سعد عبد الحميد”

'قسم التشريح_كليه الطب البشرى-جامعه قناه السويس

بقتم التشريح-كليه الطب-جامعله حلوان

"ققم الباثُولجيا الأكلنيكيه_كليه الطب البشرى- جامعه قناه السويس

مقدمة: تمثل الزيادة في أعداد المرضي الذين يعانون من أمر اض الكلي المزمنة والمر احل المتقدمة من إعتلال الكلي تحديا من أجل تطوير علاجات مبتكرة ويعتبر التداوي بالخلايا الجزعية للنخاع الشوكي من العلاجات الجذابة لأمر اض الكلي المزمنة. هاف الاراسة: تهدف هذه الدر اسة الي مقارنة الخلايا الجذعية الذاتية و الغير الذاتية المستخلصة من النخاع العظمى في علاج التغير ات الجسيمة بالكلي الناتج عن ربط الحالب فى الفئران. مواد وطرق البحث: تم تقسيم 60 فأرة بالغة إلى 4 مجمو عات رئيسية كل منها خمسة عشر فأرة بطريقه عشو ائيه. الأولى متمثلة فى المجموعة الضابطة حيث تعرضت الفئران الي نفس الإجر اءات الجر احية باستثناء ربط او تجزئة الحالب

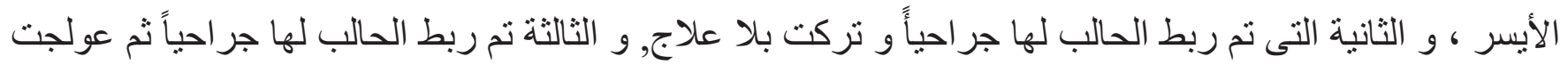
فى نفس اليوم بخلايا النخاع العظمى الغير الذاتية (المستخلصة من فأر آخر), و الر ابعة تم ربط الحالب لها جر احياً ثم عولجت فى نفس اليوم بخلايا النخاع العظمى الذاتية (المستخلصة من نفس الفأر ). وفي مجمو عه الفئر ان التى ثلقت علاج غير ذاتى كانت أعمار الفئر ان المتبر عه تقريبا متطابقة مع أعمار الفئر ان المتلقيه. النتائج: أظهرت النتائج فى هذه الدر اسه ان طريقتي العلاج بخلايا النخاع العظمى الذاتية و الغير الذاتية المستخدمة في الدراسة كان لها نأثير وقائي وقللت من حدوث انكماش واضح فى نسيج الكلية والذى أنعكس بدوره على تقليل إتساع الأنابيب الكلويه، كذلك إنخفاض في التعبير الخلالى لألفا ـ العضلات الملساء أكتين و أنخفاض بليخ فى عامل نمو المحول 1 و Caspase-3فى الخلايا الأنبوبيه.وقلل العلاج بخلايا النخاع العظمي الذاتية توسع الأنابيب الكلوية من 36.6 الي 8.13 مقارنة بتقليلها فقط الي 16.87 بو اسطة العلاج بخلايا النخاع العظمي الغير ذاتية. الخلاصه: خلصت الدر اسة الي وجود تأثير وقائي كبير علي أعتلال الكلي الناتج عن ربط الحالب في حاله العلاج بخلايا النخاع العظمي الذاتية أو الغير ذاتية. 